\title{
Evidence for plant-mediated regulation of nitrogenase expression in the Anthoceros-Nostoc symbiotic association
}

\author{
Elsie L. Campbell and John C. Meeks* \\ Department of Microbiology, University of California, Davis, California 95616, USA
}

(Received 23 September 1991; accepted 26 November 1991)

\begin{abstract}
A pleiotropic dinitrogen and nitrate assimilation mutant was obtained by mutagenesis of Nostoc sp. strain ATCC 29133 with $N$-methyl- $N^{\prime}$-nitro- $N$-nitrosoguanidine followed by penicillin counterselection in the presence of $\mathrm{NO}_{3}^{-}$and $\mathrm{N}_{2}$. Mutant strain UCD 223 was capable of reducing acetylene in the free-living growth state only under anaerobic conditions, or under atmospheric conditions when in symbiotic association with Anthoceros punctatus. Heterocysts of strain UCD 223 were noticeably lacking the cohesive outer polysaccharide layer of wild-type heterocysts. Oxygen microelectrode profiles of symbiotic Anthoceros-Nostoc tissue revealed an anaerobic environment in the symbiotic cavities containing Nostoc. The acetylene-reducing activities of strain UCD 223, and of its spontaneously-arising Fix ${ }^{+}$revertant strain UCD 236, were not repressed by the presence of $10 \mathrm{mM}-\mathrm{NO}_{3}^{-}$ when in the free-living growth state, in contrast to wild-type Nostoc ATCC 29133. However, in situ activities of acetylene reduction by symbiotically associated Nostoc ATCC 29133 and strains UCD 223 and UCD 236 were repressed by the presence of $10 \mathrm{mM}-\mathrm{NO}_{3}^{-}$. It appears that the symbiotic cavities of Anthoceros punctatus can physiologically replace the function of the heterocyst outer wall and that the repression of nitrogenase activity in symbiotic Nostoc in response to the presence of $\mathrm{NO}_{3}^{-}$, and probably $\mathrm{NH}_{4}^{+}$, is mediated by Anthoceros.
\end{abstract}

\section{Introduction}

Many cyanobacteria can grow utilizing nitrogen in different oxidation states from the environment. When ammonium is available, it is used preferentially. However, nitrate and nitrite can also be used via assimilatory nitrate and nitrite reduction to ammonium. The most complex system is that of reduction of dinitrogen gas by the oxygen-labile nitrogenase enzyme complex. In filamentous cyanobacteria classified within Sections IV and V (Rippka et al., 1979), nitrogenase is active in terminally differentiated cells called heterocysts. Heterocysts are enclosed by a unique glycolipid layer surrounded by polysaccharides which together impede the entrance of oxygen (Wolk, 1982; Murry \& Wolk, 1989). In the presence of combined nitrogen sources, the frequency of heterocysts in the filaments decreases (Fogg, 1949).

Some heterocyst-forming cyanobacteria, especially of the genus Nostoc, form symbiotic relationships with

*Author for correspondence. Tel. (916) 752 3346; fax (916) 7529014. Abbreviations: Chl $a$, chlorophyll $a$; DCMU, 3-(3,4-dichlorophenyl)1,1-dimethylurea; FW, fresh weight; MNNG, $N$-methyl- $N^{\prime}$-nitro- $N$ nitrosoguanidine. fungi and representative groups in the phylogenetic spectrum of plants (Rai, 1990). When the eukaryotic partner is photosynthetic, the heterocyst frequency of the symbiotic Nostoc increases to 30 to $60 \%$ of the total cells, compared to 3 to $8 \%$ in the free-living growth state (see Rai, 1990). These symbiotic associations are analogous to those between rhizobia and leguminous plants in that the eubacteria function in providing fixed nitrogen for the growth of the associated tissue (Stewart et al., 1980).

The bryophyte Anthoceros punctatus L. will accept as symbiotic partners a variety of Nostoc strains, which form discrete colonies within preformed cavities in the gametophyte tissue (Enderlin \& Meeks, 1983). Specific Nostoc mutant strains have been employed in defining aspects of the initial establishment and physiology of the Anthoceros-Nostoc association. Analogue-resistant mutants were used to examine competition between Nostoc strains in infection of Anthoceros tissue (Enderlin \& Meeks, 1983). In situ ${ }^{13} \mathrm{~N}$ tracer experiments using mutants of Nostoc sp. strain UCD 7801, resistant to the glutamine synthetase inhibitor L-methionine-DL-sulphoximine, established that symbiotic Nostoc releases 80 to $90 \%$ of its fixed nitrogen as ammonium to support growth of Anthoceros tissue (Meeks et al., 1985). Studies utilizing mutants of Nostoc UCD 7801, resistant to the 
photosynthetic inhibitor 3-(3,4-dichlorophenol)-1,1-dimethylurea (DCMU), provided unequivocal evidence that the Nostoc is capable of complete photosynthesis when in association with Anthoceros, albeit at a low rate (Steinberg \& Meeks, 1989), and can use its immediate photosynthate to support nitrogenase activity (Steinberg \& Meeks, 1991).

The size of the Nostoc colony in Anthoceros tissue, its rate of nitrogen fixation and frequency of heterocysts are influenced by the growth conditions of the AnthocerosNostoc association (Enderlin \& Meeks, 1983; Steinberg \& Meeks, 1991). In particular, reconstitution or growth of Anthoceros-Nostoc tissue in the presence of ammonium results in Nostoc colonies with very low to negligible rates of acetylene reduction (Enderlin \& Meeks, 1983). We are interested in the chemical interactions between partners of the Anthoceros-Nostoc association that regulate Nostoc gene expression and cellular differentiation. Our working hypothesis is that the currently undefined nitrogen regulatory mechanism controlling Nostoc heterocyst differentiation in the free-living state (Fogg, 1949) is superseded by a symbiotic control mechanism when in association with Anthoceros. To test this hypothesis, we have isolated a mutant of the symbiotically-competent Nostoc sp. strain ATCC 29133 that has defects in aerobic nitrogen fixation ( $\mathrm{Fix}^{-}$) and is also unable to assimilate exogenously supplied nitrate (assimilatory nitrate metabolism; $\mathrm{Anr}^{-}$). In this paper we describe the phenotypic characteristics of the mutant in both free-living and symbiotic growth states.

\section{Methods}

Culture and mutagenesis of Nostoc. Dinitrogen-grown cultures of Nostoc sp. strain ATCC 29133 (PCC 73102) $\left(1.4 \times 10^{9}\right.$ cells total) were mutagenized using $N$-methyl- $N^{\prime}$-nitro- $N$-nitrosoguanidine (MNNG) at $250 \mu \mathrm{g} \mathrm{ml}^{-1}$ for $4 \mathrm{~h}$ as previously described (Chapman \& Meeks, 1987). After mutagenesis, cultures were grown for approximately seven generations (14 d) at $28^{\circ} \mathrm{C}$ with continuous lighting $\left(7 \mathrm{~W} \mathrm{~m}^{-2}\right)$ in a fourfold dilution of the minimal medium of Allen \& Arnon (1955), supplemented with $5.0 \mathrm{mM}-\mathrm{MOPS} / \mathrm{NaOH}(\mathrm{pH} \mathrm{7.8)}$ and $2.5 \mathrm{~mm}$ $\mathrm{NH}_{4} \mathrm{Cl}$. This growth period allowed for segregation and expression of mutant genomes. All media, liquid and solid, used for maintenance of mutagenized cultures were buffered with 5.0 mM-MOPS/NaOH. Unless otherwise stated, all cultures were maintained under atmospheric conditions.

Prior to counterselection, cultures were harvested by centrifugation at $1000 \mathrm{~g}$ for $5 \mathrm{~min}$ and suspended in $25 \mathrm{ml}$ of medium contained in a $125 \mathrm{ml}$ flask. The flasks were then placed in a sonic cleaning bath (Branson, model 12) and subjected to sonic cavitation for sufficient time to reduce the filaments to an average length of 1.4 cells. This step was taken to minimize the amount of metabolite cross-feeding in the filaments. The fragmented cultures were twice washed with fresh medium, suspended in liquid medium supplemented with $5.0 \mathrm{mM}-\mathrm{NO}_{3}^{-}$ (equimolar sodium and potassium salts) and $0.1 \mathrm{~mm}-\mathrm{NH}_{4} \mathrm{Cl}$, and cultured for $48 \mathrm{~h}$ to recover from the shock of sonication. The cultures were then incubated for an additional $48 \mathrm{~h}$ in liquid medium supplemented only with $5.0 \mathrm{mM}-\mathrm{NO}_{3}^{-}$to induce the dinitrogen fixation and nitrate utilization systems. Mutants lacking only the aerobic $\mathbf{N}_{2}$ fixation system (Fix-) should be able to grow in the presence of $\mathrm{NO}_{3}^{-}$. Likewise, in mutants lacking the ability to assimilate $\mathrm{NO}_{3}^{-}\left(\mathrm{Anr}^{-}\right)$, there should be no repression of the $\mathrm{N}_{2}$ fixation system in the presence of $\mathrm{NO}_{3}^{-}$. Penicillin was added to a final concentration of 250 units $\mathrm{ml}^{-1}$ to enrich for those mutants lacking the ability to utilize both $\mathrm{NO}_{3}^{-}$and $\mathrm{N}_{2}$ as nitrogen sources for growth. After $48 \mathrm{~h}$ of incubation in penicillin, cultures were washed once and suspended in fresh medium supplemented with $2.5 \mathrm{mM}-\mathrm{NH}_{4} \mathrm{Cl}$. The counterselected culture was again reduced to 1-2 cell filament length by cavitation as described above and then plated onto solidified $(1 \%, \mathrm{w} / \mathrm{v}$, agar, purified using the methods of Braun \& Wood, 1962) minimal medium supplemented with $\mathrm{NH}_{4} \mathrm{Cl}$ as before.

Screenings. Isolated colonies obtained following MNNG mutagenesis and penicillin counterselection were individually picked and screened for growth on $5.0 \mathrm{mM}-\mathrm{NO}_{3}^{-}, \mathrm{N}_{2}$ or $2.5 \mathrm{~mm}-\mathrm{NH}_{4} \mathrm{Cl}$. All plates were incubated at $28^{\circ} \mathrm{C}$ with continuous lighting. The wild-type strain was included as a control on all plates. Those isolates that showed no growth, or less growth, relative to the wild-type control on the $\mathrm{NO}_{3}^{-}$ plus $\mathrm{N}_{2}$ plates were retested twice by streaking from the original $\mathrm{NH}_{4} \mathrm{Cl}$-supplemented plate on which the counterselected culture was grown.

Culture of Anthoceros. Pure cultures of gametophyte tissue of Anthoceros punctatus L. are maintained in this laboratory (Meeks, 1988). The symbiotic association with wild-type or mutant strains of Nostoc ATCC 29133 was reconstituted as described previously (Meeks, 1988). Symbiotically associated tissues were used 5-6 weeks after reconstitution.

Phenotypic characterizations. One Nostoc mutant, strain UCD 223, was chosen for further analysis. Symbiotic competence with $A$. punctatus was determined by the presence or absence of symbiotic cyanobacterial colonies and $\mathrm{N}_{2}$-dependent growth of Anthoceros tissue following co-culture of Anthoceros and the Nostoc strain in basal medium lacking combined nitrogen (Meeks, 1988). Acetylene reduction assays of symbiotic tissue and free-living cultures were performed as previously described (Enderlin \& Meeks, 1983). When specified, $10 \mathrm{mM}-\mathrm{NO}_{3}^{-}$(equimolar sodium and potassium salts) was added to the basal medium. Symbiotic cultures were washed and transferred every 3-5 d into fresh medium when grown with $\mathrm{NO}_{3}^{-}$in order to maintain the level of $\mathrm{NO}_{3}^{-}$in the medium and to control the epiphytic growth of cyanobacteria. Parallel $\mathrm{N}_{2}$-grown cultures were also transferred every 3-5 d.

Induction of anaerobic nitrogenase activity in free-living cultures of strain UCD 223 was performed as described by Murry \& Wolk (1989) in two steps: (1) $72 \mathrm{~h}$ of incubation under atmospheric conditions without nitrogen supplementation in order to promote glycogen accumulation, which subsequently serves as a carbon source and as reductant supply for nitrogenase, followed by (2) addition of $20 \mu \mathrm{M}$ DCMU (to inhibit photosynthetic $\mathrm{O}_{2}$ evolution), and incubation under argon for 12-16 $\mathrm{h}$ to allow for synthesis of the oxygen-labile nitrogenase enzyme complex. Calcium-carbide-generated acetylene gas was then added to each culture to a final concentration of $10 \%(\mathrm{v} / \mathrm{v})$ and the gas phase analysed periodically for up to $200 \mathrm{~min}$ to determine the linear rate of ethylene production. Chlorophyll $a(\mathrm{Chl} a)$ in methanolic extracts was quantified as previously described (Meeks et al., 1983).

To determine the $\mathrm{O}_{2}$ content of Anthoceros-Nostoc tissues, the tissues were secured onto $2 \%(\mathrm{w} / \mathrm{v})$ purified agar plates (buffered with $5 \mathrm{mM}$ $\mathrm{MES} / \mathrm{NaOH}$, pH 6.4) using pulled-out capillary tubes that were inserted through the periphery of the gametophyte tissue and into the agar. The plate was then flooded with fresh bryophyte growth medium with atmospheric oxygen content. Tungsten illumination was supplied at 10 inches $(25 \mathrm{~cm})$ from the tissue at an intensity of $10 \mathrm{~W} \mathrm{~m}^{-2}$ at the 
surface of the liquid. A standard Clark-type $\mathrm{O}_{2}$ microelectrode mounted in a micromanipulator (Revsbeck \& Jorgensen, 1986) was utilized to measure the $\mathrm{O}_{2}$ content within the symbiotic Nostoc colonies and adjacent Anthoceros tissue.

The ammonium content of Anthoceros and Anthoceros-Nostoc tissues, grown with $\mathrm{NH}_{4} \mathrm{NO}_{3}, \mathrm{NO}_{3}^{-}$or $\mathrm{N}_{2}$ (Enderlin \& Meeks, 1983) was determined by fluorimetry after 0 -phthalaldehyde derivatization of cell extracts (Goyal et al., 1988). Approximately $0.5 \mathrm{~g}$ fresh weight (FW) of gametophyte tissue was homogenized in $2.0 \mathrm{ml} 10 \mathrm{~mm}$ potassium phosphate, $\mathrm{pH} 6.8$. The extracts were clarified by centrifugation $(1000 \mathrm{~g}, 5 \mathrm{~min})$ and passed through $0.2 \mu \mathrm{m}$ pore size nylon filters prior to derivatization and separation by HPLC (Goyal et al., 1988). The values are reported as means \pm SE of four determinations.

In preparation for electron microscopy, symbiotic Nostoc colonies were manually excised from plant tissue with watchmaker's forceps and the aid of a stereomicroscope. Heterocysts were induced in freeliving cultures by incubation in medium without combined nitrogen ( $48 \mathrm{~h}$ for strain UCD 223) under atmospheric conditions. Symbiotic Nostoc colonies and free-living Nostoc cells were then concentrated by centrifugation at $13000 \mathrm{~g}$ and fixed in $3 \%(\mathrm{v} / \mathrm{v})$ glutaraldehyde in $0.2 \mathrm{M}-$ potassium phosphate $(\mathrm{pH} 7.0)$. Samples were post-fixed in $1 \%(w / v)$ osmium tetroxide for $2 \mathrm{~h}$ and then dehydrated in ethyl alcohol followed by a graded propylene oxide series. The samples were embedded in Medcast (Ted Pella), sectioned, and stained with uranyl acetate and lead citrate. Thin sections were examined with a Zeiss EM109 transmission electron microscope under contract with the Facility for Advanced Instrumentation, UC, Davis.

Spontaneous revertants of strain UCD 223 that had regained aerobic $\mathrm{N}_{2}$ fixation were obtained by plating $\mathrm{NH}_{4} \mathrm{Cl}$-grown cells onto solid medium with no added nitrogen source and incubation under atmospheric conditions. These Fix ${ }^{+}$revertants were screened for the ability to grow with $\mathrm{NO}_{3}^{-}$as the sole nitrogen source by inoculation onto solid medium supplemented with $\mathrm{NO}_{3}^{-}$and incubated at $10 \mathrm{~W} \mathrm{~m}^{-2}$ of illumination in a sealed clear container that was flushed continuously with $99 \%$ argon $/ 1 \% \mathrm{CO}_{2}$ (v/v). All revertants and wild-type Nostoc ATCC 29133 were also plated with no added nitrogen source and incubated under the same conditions as controls. All revertants and Nostoc ATCC 29133, on an $\mathrm{NH}_{4} \mathrm{Cl}$-supplemented plate and incubated under atmospheric conditions, were included in parallel for verification of viability. Growth relative to the wild-type strain under all three conditions was noted following 2 weeks of incubation.

\section{Results}

Isolation and characteristics of a Fix ${ }^{-}$Anr- mutant of Nostoc sp. strain ATCC 29133

Following mutagenesis and counterselection, 1150 isolates were subjected to three successive screenings and yielded one clone, Nostoc strain UCD 223, with a stable pleiotropic aerobic $\mathrm{Fix}^{-}$and $\mathrm{Anr}^{-}$phenotype. All other 191 putative mutants from the initial screening displayed an ability to grow with $\mathrm{N}_{2}$ and/or $\mathrm{NO}_{3}^{-}$in subsequent screenings. Strain UCD 236 is a spontaneous aerobic $\mathrm{Fix}^{+}$revertant of strain UCD 223; such spontaneous reversion to $\mathrm{Fix}^{+}$occurred at a frequency of approximately $10^{-9}$. Strain UCD 236 was unable to grow on $\mathrm{NO}_{3}^{-}$in a $99 \%$ argon $/ 1 \% \mathrm{CO}_{2}$ atmosphere, whereas Nostoc ATCC 29133 showed extensive growth following 2 weeks of incubation under the same conditions. Nostoc ATCC 29133, however, displayed little or no growth
Table 1. Acetylene reduction activity of Nostoc ATCC 29133 and its derivative strains

All values are means $\pm \mathrm{SE} ; \boldsymbol{n}$ is the number of trials. No acetylene reduction was observed with any of the three strains in the freeliving state with $2.5 \mathrm{mM}-\mathrm{NH}_{4}^{+}$as the nitrogen source (acetylene reduction was not determined for the symbiotic association under these conditions).

\begin{tabular}{|c|c|c|}
\hline \multirow[b]{2}{*}{ Strain* } & \multicolumn{2}{|c|}{ Acetylene reduction activity } \\
\hline & $10 \mathrm{mM}^{-\mathrm{NO}_{3}^{-}}$ & $\mathbf{N}_{2}$ \\
\hline & \multicolumn{2}{|c|}{ 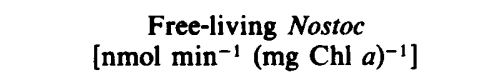 } \\
\hline 29133 & $\begin{array}{c}19.8 \pm 9 \\
(n=4)\end{array}$ & $\begin{array}{c}132 \pm 24 \\
(n=2)\end{array}$ \\
\hline $223 \dagger$ & $\begin{array}{l}45 \cdot 0 \\
(n=1)\end{array}$ & $\begin{array}{l}54 \pm 26 \\
(n=4)\end{array}$ \\
\hline \multirow[t]{2}{*}{236} & $\begin{array}{c}120 \cdot 0 \pm 18 \\
(n=3)\end{array}$ & $\begin{array}{c}109 \pm 18 \\
(n=3)\end{array}$ \\
\hline & \multicolumn{2}{|c|}{$\begin{array}{l}\text { Anthoceros-Nostoc association } \\
\text { (pmol } \mathrm{min}^{-1} \text { per colony) }\end{array}$} \\
\hline 29133 & $\begin{array}{l}12 \cdot 7 \pm 1 \\
(n=3)\end{array}$ & $\begin{array}{l}27.9 \pm 3 \\
(n=8)\end{array}$ \\
\hline 223 & $24(n=1)$ & $\begin{array}{l}97 \pm 6 \\
(n=5)\end{array}$ \\
\hline 236 & $\begin{array}{r}7 \cdot 0 \pm 1 \cdot 0 \\
(n=2)\end{array}$ & $\begin{array}{l}27 \cdot 0 \pm 1 \\
(n=18)\end{array}$ \\
\hline
\end{tabular}

* Strain ATCC 29133 is the wild-type, strain UCD 223 is a Fix ${ }^{-}$ Anr $^{-}$mutant derived from ATCC 29133, strain UCD 236 is a Fix ${ }^{+}$ Anr- $^{-}$revertant of strain UCD 223.

$\dagger$ Activities were measured in the presence of $20 \mu \mathrm{M}-\mathrm{DCMU}$ and argon (see Methods).

under the argon $/ \mathrm{CO}_{2}$ atmosphere when plated on medium containing no nitrogen source.

Nostoc UCD 223 was able to establish an initially functional symbiotic association with Anthoceros. The rate of acetylene reduction, normalized to the number of symbiotic colonies, was about three fold higher than that of the association with Nostoc ATCC 29133 (Table 1). However, when normalized to $\mathrm{g}$ FW of Anthoceros tissue, the rate with strain UCD 223 was approximately fivefold lower than that with ATCC 29133 (data not shown). Since Anthoceros tissue associated with strains UCD 223 and ATCC 29133 contained an average of $23 \pm 4(n=9)$ and $1176 \pm 153(n=9)$ colonies per $\mathrm{g} \mathrm{FW}$, respectively, the lower rate of acetylene reduction by strain UCD 223, normalized to $\mathrm{FW}$, was apparently a consequence of a lower infection frequency. The association with strain UCD 223 eventually ceased to grow with $\mathrm{N}_{2}$ as the nitrogen source due to a lack of the reinfection of the marginal meristematic region of Anthoceros tissue that occurs in associations with wild-type Nostoc strains.

Electron micrographs show that the heterocysts of strain UCD 223 in the free-living and symbiotic growth states (Fig. 1 $a, d$ ) lack the complete outer polysaccharide layer characteristic of heterocysts in the wild-type strain 

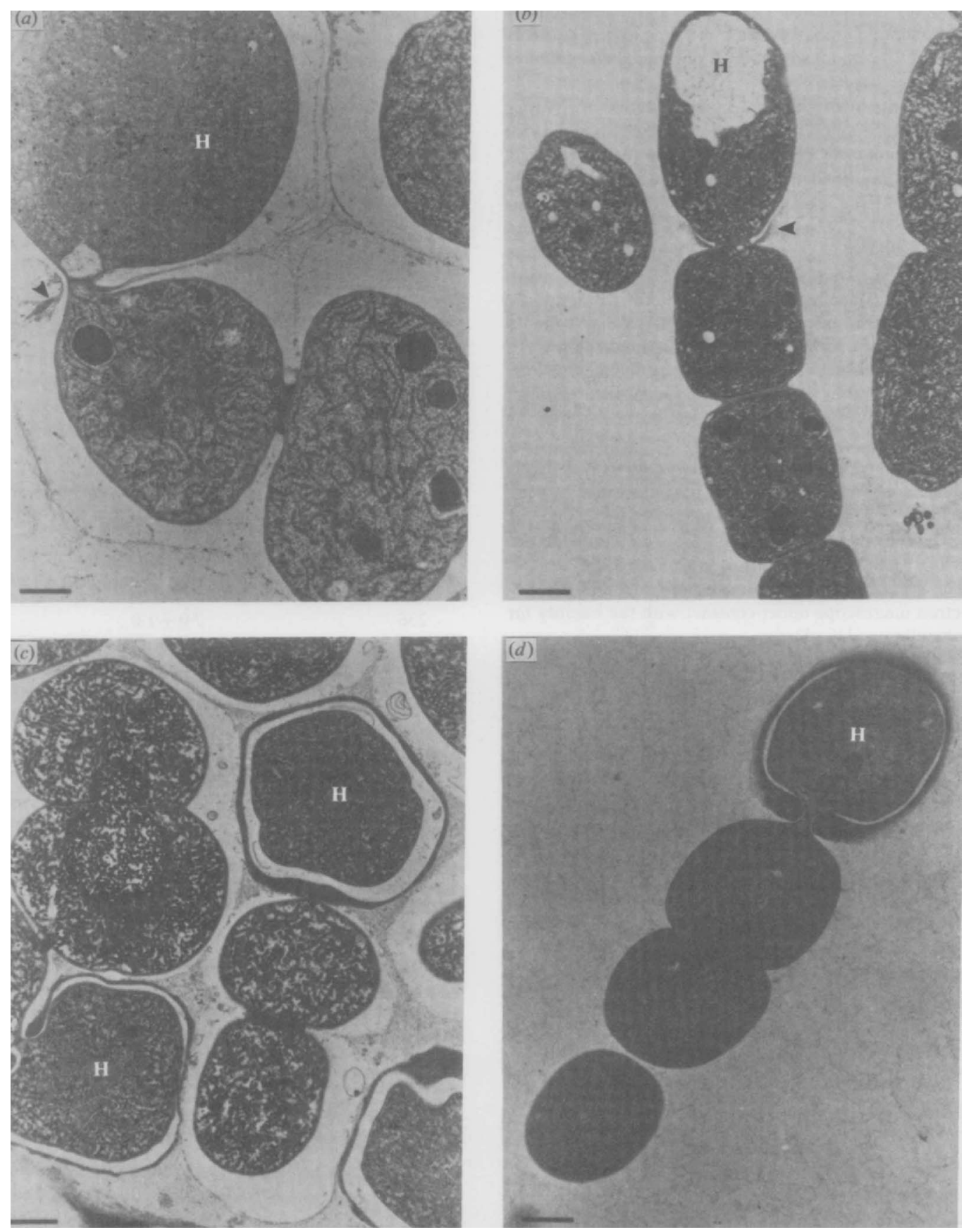

Fig. 1. $(a, b)$ Transmission electron micrographs of Nostoc UCD 223 in symbiotic association with Anthoceros punctatus $(a)$ and in the free-living growth state $(b) .(c, d)$ Nostoc ATCC 29133, symbiotically associated $(c)$ and free-living $(d)$. Bars, $1 \mu \mathrm{m}$. Arrowheads in $(a)$ and $(b)$ indicate the abnormal outer polysaccharide layer of mutant heterocysts. $\mathrm{H}$, heterocyst.

(Fig. $1 c, d)$. The residual polysaccharide layer of mutant heterocysts was most apparent at adjacent cell junctions (see arrowheads in Fig. $1 a, b$ ). Heterocysts of strain UCD 223 had a less distorted shape and a more cohesive cytoplasm in the symbiotic, compared to the free-living, growth state, perhaps as a consequence of osmotic stabilization. The distorted shapes of the heterocysts in free-living cultures of strain UCD 223 were clearly visible in the light microscope (data not shown).

Free-living cultures of strain UCD 223 were able to reduce acetylene under anaerobic incubation conditions at a rate that was less than $50 \%$ that of Nostoc 
ATCC 29133 incubated under atmospheric conditions (Table 1). Consistent results were obtained only after cultures of strain UCD 223 had been starved for $\mathrm{NH}_{4}^{+}$in the light under atmospheric conditions to supplement internal pools of stored photosynthate prior to anaerobic induction of nitrogenase (see Murry \& Wolk, 1989). Low and variable rates of acetylene reduction were seen if the cultures were starved for $\mathrm{NH}_{4}^{+}$under anaerobic conditions in the presence of $20 \mu \mathrm{M}$-DCMU and $10 \mathrm{mM}$ fructose (data not shown).

\section{Oxygen tension in symbiotic Nostoc colonies}

The observations that strain UCD 223 was able to reduce acetylene only under anaerobic conditions in the freeliving growth state, but under normal atmospheric conditions when in symbiotic association, implied that the oxygen tension could be low in the symbiotic Nostoc colony. The $\mathrm{O}_{2}$ concentration profile of AnthocerosNostoc tissue, as measured with a microelectrode, is shown in Fig. 2. The dissolved $\mathrm{O}_{2}$ content of the medium at the surface of Anthoceros tissue was $259 \mu \mathrm{M}$ as determined with the microelectrode. The Anthoceros tissue at approximately $80-950 \mu \mathrm{m}$ internal from the surface of the tissue and $600-3000 \mu \mathrm{m}$ from the nearest symbiotic Nostoc colony contained an average of $157 \pm 12 \mu \mathrm{M} \mathrm{O}_{2}(n=15)$, or $60 \%$ of the $\mathrm{O}_{2}$ content of the medium. The Anthoceros cavity housing symbiotic Nostoc (strain ATCC 29133 or UDC 223) contained no measurable $\mathrm{O}_{2}$. Symbiotic tissue with wild-type Nostoc sp. strains UCD 7801 or ATCC 27896 displayed the same decrease in $\mathrm{O}_{2}$ in the adjacent Anthoceros tissue leading to no measurable $\mathrm{O}_{2}$ within the symbiotic cavity (data not shown).

The symbiotic colonies of Nostoc strain UCD 223 were larger than those of strain ATCC 29133 of the same age. As shown in Fig. 2, the strain UCD 223 symbiotic colony after 6 weeks of co-culture with Anthoceros was approximately $780 \mu \mathrm{m}$ in depth, whereas symbiotic Nostoc ATCC 29133 colonies of the same age were approximately $600 \mu \mathrm{m}$ in depth; similar results were observed in other randomly selected colonies. The larger colonies of strain UCD 223 are consistent with its higher rate of symbiotic acetylene reduction when normalized to number of colonies (Table 1). When reisolated from symbiotic association, strain UCD 223 retained its aerobic $\mathrm{Fix}^{-}$and $\mathrm{Anr}^{-}$phenotype.

\section{Effect of nitrate on free-living and symbiotic nitrogenase expression by wild-type and Anr- strains}

Acetylene-reducing activities of strain UCD 223 in the presence of argon and DCMU were similar with or without $\mathrm{NO}_{3}^{-}$in the medium (Table 1). The kinetics of
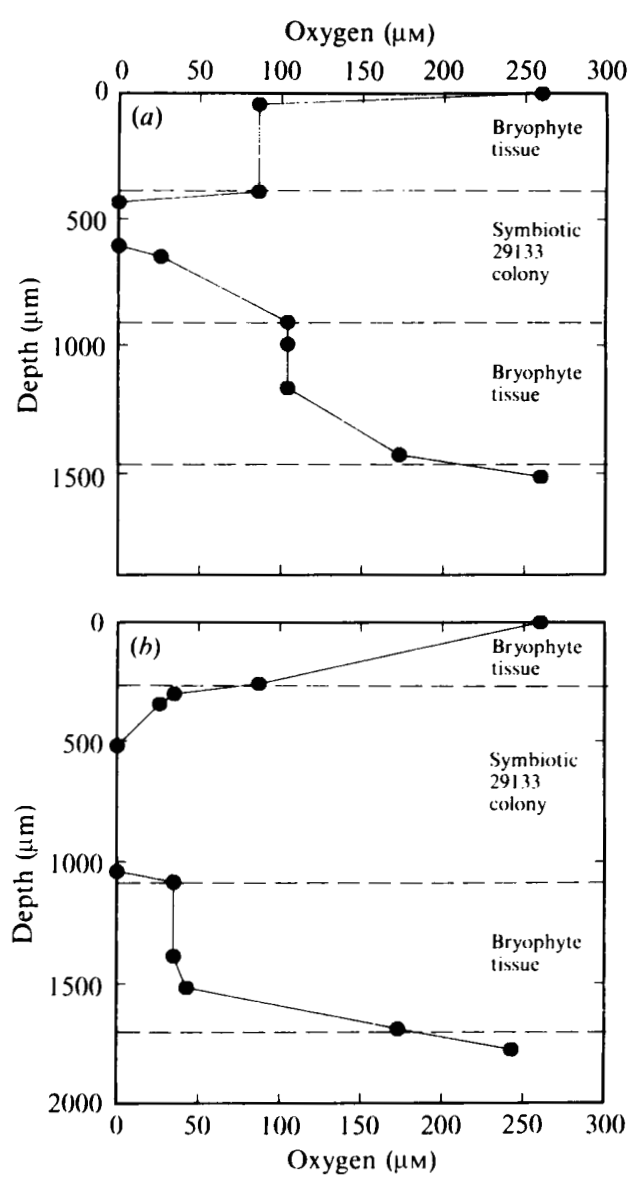

Fig. 2. Oxygen concentration profile of Anthoceros gametophyte tissue and associated colonies of Nostoc ATCC 29133 (a) and UCD 223 (b), measured after 6 weeks of co-culture. Each profile is a representative of three trials.

induction of nitrogenase in the absence or presence of combined nitrogen were examined in an aerobic $\mathrm{Fix}^{+}$ revertant of strain UCD 223. Strain UCD 236 (Fix $^{+}$ $\mathrm{Anr}^{-}$) was used to avoid physiological variability and the experimental complications of maintaining an anaerobic environment during incubation of these Nostoc strains, which grow preferentially as oxygenic photoautotrophs. Acetylene-reducing activity of strain UCD 236 showed the same induction kinetics following transfer from $\mathrm{NH}_{4}^{+}$ into the absence or presence of $\mathrm{NO}_{3}^{-}$(Fig. $3 b$ ). The activity of the wild-type strain, however, was inhibited $85 \%$ in the presence of $\mathrm{NO}_{3}^{-}$relative to the fully induced rate after $4 \mathrm{~d}$ of incubation (Table 1, Fig. $3 a$ ). When in symbiotic association with Anthoceros, the acetylenereducing activity of all three strains (ATCC 29133, UCD 223 and UCD 236) was repressed in the presence of $10 \mathrm{~mm}-\mathrm{NO}_{3}^{-}$when compared with the parallel $\mathrm{N}_{2}-$ grown cultures $(54 \%, 75 \%$ and $74 \%$ repression, respectively; Table 1, Fig. 4). Strains UCD 223 and UCD 236, 


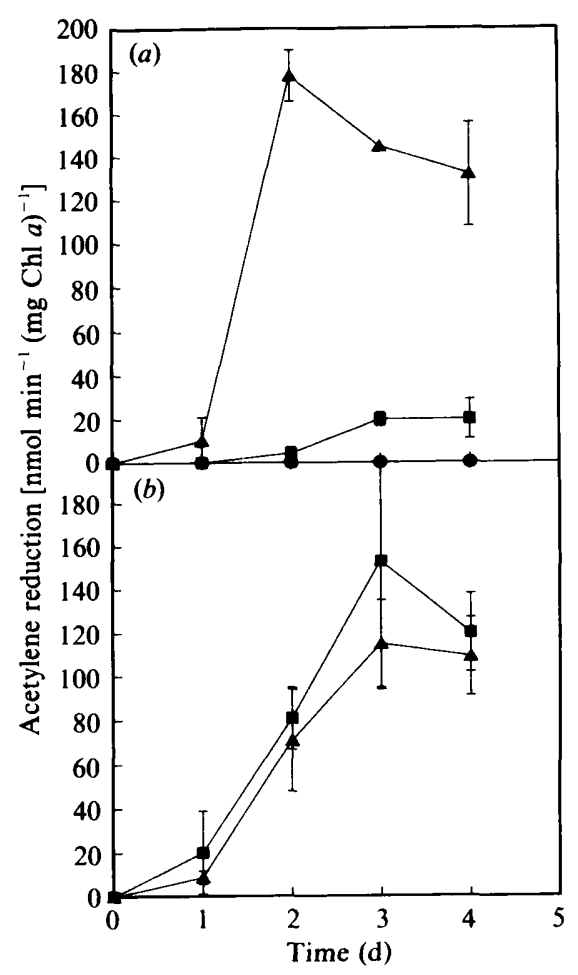

Fig. 3. Acetylene reduction rates of $\mathrm{NH}_{4}^{+}$-grown free-living Nostoc cultures transferred at $t=0$ to medium with: no nitrogen supplement (A), $10 \mathrm{~mm}-\mathrm{NO}_{3}^{-}(\boldsymbol{\theta})$, or $2.5 \mathrm{~mm}-\mathrm{NH}_{4}^{+}(O)$. (a) Strain ATCC 29133; (b) strain UCD 236. Each datum point represents the mean of 2-4 trials $\pm \mathrm{SE}$.

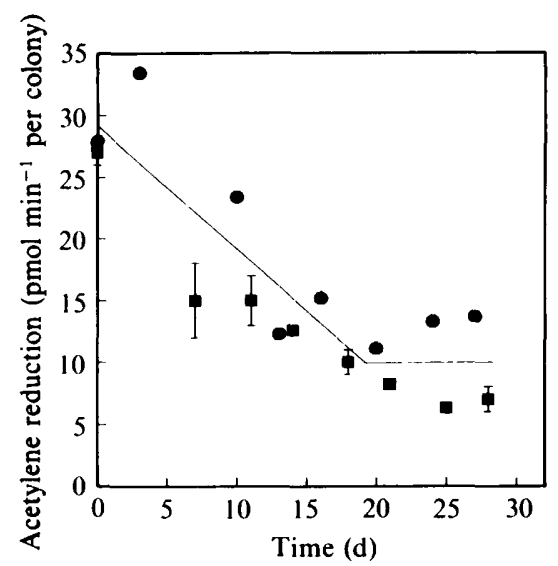

Fig. 4. In situ acetylene reduction rates following the addition of $10 \mathrm{~mm}$ $\mathrm{NO}_{3}^{-}$to Anthoceros tissue previously reconstituted with Nostoc ATCC $29133(0)$ or UCD $236(\square)$. $\mathrm{NO}_{3}^{-}$was added at $t=0$ in both cases. $n=1$ for strain ATCC 29133; $n=2 \pm$ SE for strain UCD 236.

reisolated from $\mathrm{NO}_{3}^{-}$-grown symbiotic associations and cultured in the free-living state, did not grow with $\mathrm{NO}_{3}^{-}$ as sole nitrogen source.

The $\mathrm{NH}_{4}^{+}$content of symbiont-free Anthoceros tissue, grown with $\mathrm{NH}_{4} \mathrm{NO}_{3}$, was $2.35 \pm 0.17 \mu \mathrm{mol}(\mathrm{g} \mathrm{FW})^{-1}$.
Symbiont-free Anthoceros and Anthoceros-Nostoc UCD 236 tissues cultured with $10 \mathrm{~mm}-\mathrm{NO}_{3}^{-}$for more than $14 \mathrm{~d}$ (transferred every $3-5 \mathrm{~d}$ ) contained $0 \cdot 12 \pm 0 \cdot 01$ and $0 \cdot 14 \pm 0.01 \mu \mathrm{mol} \mathrm{NH}_{4}^{+}(\mathrm{g} \mathrm{FW})^{-1}$. These values are very similar to those found in $\mathrm{N}_{2}$-grown AnthocerosNostoc ATCC $29133(0 \cdot 12 \pm 0 \cdot 01)$.

\section{Discussion}

MNNG mutagenesis followed by penicillin counterselection in the presence of $\mathrm{NO}_{3}^{-}$and $\mathrm{N}_{2}$ was an effective method to obtain a mutant defective in two nitrogen assimilatory functions. There are three possible explanations for this pleiotropic phenotype. First, there could be a mutation in a common regulatory gene. The existence of a common nitrogen regulatory gene has been reported in the unicellular cyanobacterium Synechococcus sp. strain PCC 7942 (Vega-Palas et al., 1990) and global regulatory proteins have how been identified in cyanobacteria (Tsinoremas et al., 1991). Second, there could be a mutation in a common cofactor for activity, such as molybdate processing ( $\mathrm{ChlD}^{-}$phenotype; Shah et al., 1984). Third, the strain could carry multiple mutations in structural genes. Strain UCD 223 appears to be representative of the latter category. Elevation of the molybdenum concentration in the medium did not restore growth of strain UCD 223 on $\mathrm{NO}_{3}^{-}$or $\mathrm{N}_{2}$ (data not shown), as occurs in molybdate-processing mutants (Shah et al., 1984). Spontaneous reversion to both $\mathrm{N}_{2}$ and $\mathrm{NO}_{3}^{-}$prototrophy has not been obtained after plating more than $10^{12}$ cells and reversion to $\mathrm{NO}_{3}^{-}$prototrophy alone occurs at a frequency approximately fivefold higher than reversion to $\mathrm{N}_{2}$ prototrophy. We have no specific information about the mutation leading to the Anr- phenotype. However, electron micrographs showing incomplete formation of the polysaccharide layer (Fig. 1) indicate that strain UCD 223 carries mutations in a gene(s) encoding synthesis of a component(s) of the heterocyst envelope. The fact that strain UCD 223 could reduce acetylene under anaerobic incubation conditions is evidence that the mutation results in loss of $\mathrm{O}_{2}$ protection for either synthesis or catalytic activity of nitrogenase.

Normalized rates of acetylene reduction by Nostoc strain UCD 223 in symbiosis were greater than those by strain ATCC 29133 (Table 1), indicating that the $\mathrm{O}_{2}$ protection function of the outer heterocyst wall could be substituted by the environment within the symbiotic cavity of Anthoceros. Such a micro-oxic environment was verified by direct microelectrode measurements (Fig. 2). Nostoc UCD 7801 in association with Anthoceros is capable of complete photosynthesis at a rate approximately $15 \%$ of that expressed in the free-living growth state (Steinberg \& Meeks, 1989). Thus, a micro-oxic environ- 
ment within the tissue of a symbiotic association involving two $\mathrm{O}_{2}$-evolving photosynthetic partners was not expected. Ultrastructural analyses of AnthocerosNostoc tissues have provided no evidence for the presence of a structural barrier to $\mathrm{O}_{2}$ diffusion within symbiotic cavities (Rodgers \& Stewart, 1977; Duckett $\boldsymbol{e t}$ al., 1977). A similar low $\mathrm{O}_{2}$ tension in cyanobacterialinhabited coralloid roots of cycads has been inferred from assays of nitrogenase activity, but there have been no direct measurements (Lindblad et al., 1991). We suggest the low $\mathrm{O}_{2}$ tension in the Anthoceros-Nostoc symbiotic cavity, and perhaps cycad roots, is a consequence of the respiratory activities of both partners. The fact that Anthoceros gametophyte tissue had a lower than ambient $\mathrm{O}_{2}$ content (Fig. 2) implies that the overall rate of photosynthetic $\mathrm{O}_{2}$ production did not greatly exceed the rate of respiratory $\mathrm{O}_{2}$ consumption under the specific culture conditions.

Since strain UCD 223 is unable to fix nitrogen in an aerobic environment, it is unable to grow outside of the symbiotic cavity in medium lacking combined nitrogen. This limitation may contribute to its inability to reinfect marginal meristematic regions of the plant and establish new symbiotic colonies; $\mathrm{Fix}^{+}$revertants of strain UCD 223 do reinfect Anthoceros tissue. The relatively large size of existing symbiotic colonies of strain UCD 223, and accompanying high rate of acetylene reduction, may occur in response to the lack of new infections, whereby the existing colonies provide more fixed nitrogen in an attempt to support the growing bryophyte tissue. A similar response was observed after Anthoceros-Nostoc tissues had been treated with penicillin to remove epiphytic growth of Nostoc (Enderlin \& Meeks, 1983).

The presence of $\mathrm{NH}_{4}^{+}$or $\mathrm{NO}_{3}^{-}$repressed nitrogenase expression in Nostoc ATCC 29133 (Table 1, Fig. 3). Nitrate repression is thought to be mediated through its reduction to $\mathrm{NH}_{4}^{+}$by the assimilatory nitrate and nitrite reductases and subsequent assimilation of the $\mathrm{NH}_{4}^{+}$into organic molecules (Van Baalen, 1987). The mechanism by which assimilated $\mathrm{NH}_{4}^{+}$is sensed and represses heterocyst differentiation and nitrogenase expression is unknown. A protein homologous to the PII sensing protein of the nitrogen regulatory system in enteric bacteria (Bueno et al., 1985) and nucleotide sequences homologous to the gene encoding a bifunctional protein kinase-phosphoprotein phosphatase (ntrB; Keener \& Kustu, 1988) were recently identified in cyanobacteria (Tsinoremas et al., 1991). These observations suggest the presence of an analogous nitrogen regulatory system in cyanobacteria. As predicted by their Anr ${ }^{-}$phenotype, free-living cultures of strains UCD 223 and UCD 236 induced and maintained the same level of nitrogenase activity in the presence or absence of exogenous $\mathrm{NO}_{3}^{-}$
(Table 1, Fig. 3). Nevertheless, the presence of nitrate repressed acetylene-reducing activity to a similar extent in Anthoceros associations with Nostoc ATCC 29133 and with strains UCD 223 and UCD 236 (Table 1, Fig. 4). It is possible that the $\mathrm{NO}_{3}^{-}$was reduced to $\mathrm{NH}_{4}^{+}$by Anthoceros and excess $\mathrm{NH}_{4}^{+}$released into the symbiotic cavity where it functioned to repress nitrogenase in symbiotic Nostoc. The pools of $\mathrm{NH}_{4}^{+}$in tissues of $\mathrm{NO}_{3}^{-}$grown Anthoceros or Anthoceros-Nostoc, however, were identical to those present in $\mathrm{N}_{2}$-grown AnthocerosNostoc. The resulting decrease in nitrogenase activity in the presence of exogenous $\mathrm{NO}_{3}^{-}$must have been mediated by a change in extracellular signals, other than $\mathrm{NH}_{4}{ }^{+}$, transferred from Anthoceros to Nostoc.

We conclude that the mechanism(s) regulating the high level of symbiotic heterocyst differentiation and nitrogenase expression of Nostoc in association with Anthoceros is distinctly different from that involved in the free-living growth state. The apparent lack of direct nitrogen repression and the existence of a microaerobic to anaerobic environment are strikingly similar to the conditions involved in bacteroid differentiation and nitrogenase expression by rhizobia in association with leguminous plants (Long, 1989).

This work was supported in part by the California Agricultural Experiment Station (project number CAD-3620-H), the National Science Foundation (grant DCB 8902204), and the United States Department of Agriculture Competitive Research Grants Office (grant 90-37120-5602). We thank Dr Doug Nelson for his assistance in performing the oxygen microelectrode experiments, Dr Sham Goyal for analysis of $\mathrm{NH}_{4}^{+}$by HPLC, and Mr Rudolph Addison for electron microscopy.

\section{References}

Allen, M. \& ARnON, D. I. (1955). Studies on nitrogen-fixing bluegreen algae. I. Growth and nitrogen fixation by Anabaena cylindrica Lemm. Plant Physiology 30, 366-372.

Braun, A. C. \& WoOD, H. N. (1962). On activation of certain essential biosynthetic systems in cells of Vinca rosea L. Proceedings of the National Academy of Sciences of the United States of America 48, 1776-1782.

Bueno, R., Rahel, G. \& MAGASANIK, B. (1985). Role of $g \ln B$ and $g \ln D$ gene products in regulation of the glnALG operon of Escherichia coli. Journal of Bacteriology 164, 816-822.

Chapman, J. S. \& Meeks, J. C. (1987). Conditions for mutagenesis of the nitrogen-fixing cyanobacterium Anabaena variabilis. Journal of General Microbiology 133, 111-118.

Duckett, J. G., Prasad, A. K. S. K., Davies, D. A. \& Walker, S. (1977). A cytological analysis of the Nostoc-bryophyte relationship. New Phytologist 79, 349-362.

Enderlin, C. S. \& MeEks, J. C. (1983). Pure culture and reconstitution of the Anthoceros-Nostoc symbiotic association. Planta 158, 157-165.

FoGG, G. E. (1949). Growth and heterocyst production in Anabaena cylindrica Lemm. II. In relation to carbon and nitrogen metabolism. Annals of Botany, New Series 13, 241-259.

Goyal, S. S., RaIns, D. W. \& Huffaker, R. C. (1988). Determination of ammonium ion by fluorometry or spectrophotometry after on-line derivatization with o-phthalaldehyde. Analytical Chemistry 60, 175179. 
Kegner, J. \& Kustu, S. (1988). Protein kinase and phosphoprotein phosphatase activities of nitrogen regulatory proteins NTRB and NTRC of enteric bacteria: role of the conserved amino-terminal domain of NTRC. Proceedings of the National Academy of Sciences of the United States of America 85, 4976-4980.

Lindblad, P., AtKins, C. A. \& Pate, J. S. (1991). N $\mathbf{N}_{2}$-fixation by freshly isolated Nostoc from coralloid roots of the cycad Macrozamia riedlei (Fisch. ex Gaud.) Gardn. Plant Physiology 95, 753759.

LoNG, S. R. (1989). Rhizobium-legume nodulation: life together in the underground. Cell 56, 203-214.

MeEks, J. C. (1988). Symbiotic associations. Methods in Enzymology 167, 113-121.

Meeks, J. C., Wycoff, K. L., Chapman, J. S. \& Enderlin, C. S. (1983). Regulation of expression of nitrate and dinitrogen assimilation by Anabaena species. Applied and Environmental Microbiology 45, 1351-1359.

Meeks, J. C., Enderlin, C. S., Joseph, C. M., Chapman, J. S. \& LOLLAR, M. W. L. (1985). Fixation of $\left[{ }^{13} \mathrm{~N}\right] \mathrm{N}_{2}$ and transfer of fixed nitrogen in the Anthoceros-Nostoc symbiotic association. Planta 164, 406-414.

MURRY, M. A. \& Wolk, C. P. (1989). Evidence that the barrier to the penetration of oxygen into heterocysts depends upon two layers of the cell envelope. Archives of Microbiology 151, 469-474.

RAI, A. N. (editor) (1990). Handbook of Symbiotic Cyanobacteria, Boca Raton, Florida: CRC Press.

Rippka, R., Deruelles, J. Waterbury, J. B., Herdman, M. \& Stanier, R. Y. (1979). Generic assignments, strain histories and properties of pure cultures of cyanobacteria. Journal of General Microbiology 111, 1-61.

Rodgers, G. A. \& SteWART, W. D. P. (1977). The cyanophyte-hepatic symbiosis. I. Morphology and physiology. New Phytologist 78, 441458.
ReVSBECH, N. P. \& JoRgensen, B. B. (1986). Microelectrodes: their use in microbial ecology. In Advances in Microbial Ecology, vol. 9, pp. 293-352. Edited by K. C. Marshall. New York: Plenum Press.

Shah, V. K., Ugalde, R. A., Imperial, J. \& Brill, W. J. (1984). Molybdenum in nitrogenase. Annual Review of Biochemistry 53, 231257.

Steinberg, N. A. \& Meeks, J. C. (1989). Photosynthetic $\mathrm{CO}_{2}$ fixation and ribulose bisphosphate carboxylase/oxygenase activity of Nostoc sp. strain UCD 7801 in symbiotic association with Anthoceros punctatus. Journal of Bacteriology 171, 6227-6233.

SteinberG, N. A. \& MeEks, J. C. (1991). Physiological sources of reductant for nitrogen fixation activity of Nostoc sp. strain UCD 7801 in symbiotic association with Anthoceros punctatus. Journal of Bacteriology 173, 7324-7329.

Stewart, W. D. P., Rowell, P. \& RaI, A. N. (1980). Symbiotic nitrogen-fixing cyanobacteria. In Nitrogen Fixation, pp. 239-277. Edited by W. D. P. Stewart \& J. R. Gallon. New York \& London: Academic Press.

Tsinoremas, N. F., Castets, A. M., Harrison, M. A., Allen, J. F. \& Tandeau De Marsac, N. (1991). Photosynthetic electron transport controls nitrogen assimilation in cyanobacteria by means of posttranslational modification of the glnB gene product. Proceedings of the National Academy of Sciences of the United States of America 88, 4565-4569.

VAN BAALEN, C. (1987). Nitrogen fixation. In The Cyanobacteria, pp. 187-198. Edited by P. Fay \& C. Van Baalen. Amsterdam: Elsevier.

Vega-Palas, M. A., Madueno, F., Herrero, A. \& Flores, E. (1990). Identification and cloning of a regulatory gene for nitrogen assimilation in the cyanobacterium Synechococcus sp. strain PCC 7942. Journal of Bacteriology 172, 643-647.

Wolk, C. P. (1982). Heterocysts. In The Biology of Cyanobacteria, pp. 359-386. Edited by N. G. Carr \& B. A. Whitton. Oxford: Blackwell Scientific Publications. 